\title{
Dietary supplementation of mannanoligosaccharides to turkey hens on their growth performance and antioxidant status in the blood
}

\author{
K. Ognik \& M. Krauze \\ Department of Biochemistry and Toxicology, Faculty of Animal Biology and Breeding, University of Life Sciences, \\ 20-950 Lublin, Poland
}

\begin{abstract}
The research focused on the effect of a prebiotic additive, mannanoligosaccharides (Bio-Mos), in the diet of turkey hens on their growth performance and measurements of pro-oxidation and antioxidation systems in their blood. The investigation was performed on 240 six-week-old turkey hens of the heavy Big- 6 breed, randomly divided into two groups. Group I was the control group, whereas the birds in group II were fed the control diet with a $0.5 \%$ addition of Bio-Mos. Bio-Mos did not increase the concentration of lipid peroxidation products, peroxide $\mathrm{H}_{2} \mathrm{O}_{2}$ and malone dialdehyde. However, it contributed to the increased concentration of some antioxidation parameters such as vitamin C, iron and zinc in the blood. Moreover, it led to an improved growth performance. The study suggested that mannanoligosaccharides can be used in practice as a dietary additive for turkeys, stimulating the mechanisms of the birds' antioxidation defence and improving their growth performance.
\end{abstract}

Keywords: Bio-Mos, prebiotic, effects of rearing, redox parameters

\#Corresponding author: kasiaognik@poczta.fm

\section{Introduction}

To strengthen the resistance of poultry against pathogenic agents, additives with immunomodulating characteristics, among others prebiotics, are increasingly being used in the animal feed industry. A prominent product in this group is mannanoligosaccharides (Bio-Mos), which consists of complex carbohydrates isolated from the cellular wall of baker's yeast, Saccharomyces cerevisiae (Parks et al., 2005; Baurhoo et al., 2007; Dobicki et al., 2007). Bio-Mos supports $\beta$-glucans in stimulating defence mechanisms in the body, activating digestive enzymes, increasing the absorption of nutrients from feed owing to its ability to bind pathogenic bacteria and neutralizing toxins excreted by such bacteria (Oguz \& Parlat, 2004; Zaghini et al., 2005). This lead to improved poultry performance and lowered susceptibility to infections of the digestive and respiratory systems (Mikulski et al., 2008). Because mannanoligosaccharides are not digested, they are found in their unaltered form in the small intestine, where they stimulate the intestinal flora and thus immunological processes (Dobicki et al., 2007). Hence, stimulating the lymphatic system of the gastrointestinal tract is partly translated into an organism's general immunity (Zduńczyk et al., 2005; Czech \& Grela, 2006; Milewski et al., 2007; Czech et al., 2009; Milewski, 2009). Research by Zduńczyk et al. (2005) and Świątkiewicz \& Koreleski (2007) confirmed the immuno-stimulating properties of this compound. Since the immunological and antioxidation systems are mutually complementary mechanisms, it is of interest to determine the effect of mannanoligosaccharides on the pro- and antioxidant status of the organism, as well as on growth performance.

The aim of the study was to determine the influence of adding mannanoligosaccharides to the diet of turkey hens on the level of pro-oxidation and antioxidation indices of their blood and on their performance. 


\section{Materials and Methods}

The study was conducted on 240 six-week-old turkey hens of the heavy Big-6 type, randomly divided into two groups of 120 birds each. Until their 16th week of life, the birds were kept on straw bedding in hen coops, each housing 20 birds (6 replications for each group). Finishing of the hens was carried out under standard zoological and hygienic conditions, in compliance with the recommendations of Faruga \& Jankowski (1996). Throughout the experiment, the turkey hens received a standard full-portion diet ad libitum, produced by Provimi Poland, following the programme comprising of five feeding periods. The hens had constant access to drinking water. The nutrient content of the diets was in compliance with NRC (1994) recommendations. Group I was the control group and the birds in group II received the control diet supplemented with 0.5\% mannanoligosaccharides, Bio-Mos (a natural preparation of Alltech, Poland). At the end of the 9th and 16th weeks of the birds' lives, blood samples were taken for biochemical analyses from their brachial veins, each time from the same 20 birds in every group. Blood plasma samples were used to determine the concentration of uric acid, urea, bilirubin, creatinine and albumin with the use of monotests developed by Cormay. Additionally, the concentrations of zinc, copper and iron were determined in blood plasma, using atomic absorption spectrophotometry. The activity of superoxide dismutase (SOD, EC 1.5.1.1) was recorded spectrophotometrically in the birds' blood plasma with the use of the adrenalin method, following Misra in Greenwald (1985) with a modification in the length of $320 \mathrm{~nm}$ (Bartosz, 2004). Also, the activity of catalase (CAT, EC 1.11.1.6) was determined according to Bartosz (2004). Total antioxidation potential of the plasma (FRAP) was measured according to Benzie \& Strain (1996). Plasma was used to record the concentrations of lipid peroxidation products: Superoxide, according to Gay \& Gębicki (2002) and malone dialdehyde as the final product of lipid oxidation, according to Ledwożyw et al. (1986). The content

Table 1 Ingredient and nutrient content of the standard experimental diets

\begin{tabular}{lccc}
\hline $\begin{array}{l}\text { Ingredient } \\
\text { (Feeding period) }\end{array}$ & $\begin{array}{c}\text { Grower } 1 \\
(6-9 \text { week })\end{array}$ & $\begin{array}{c}\text { Grower } 2 \\
(10-13 \text { week })\end{array}$ & $\begin{array}{c}\text { Finisher } 1 \\
(14-16 \text { week })\end{array}$ \\
\hline Maize (\%) & 25.0 & 25.0 & 20.0 \\
Wheat (\%) & 30.6 & 36.8 & 56.6 \\
Soybean (\%) & 33.5 & 28.0 & 15.0 \\
Meat and bone meal (\%) & 5.00 & 5.00 & 4.0 \\
Soya oil (\%) & 2.00 & 2.00 & 1.2 \\
Limestone (\%) & 0.70 & 0.50 & 0.50 \\
Cytromix Plus ${ }^{1}(\%)$ & 0.20 & 0.20 & 0.20 \\
Farmix ${ }^{2}(\%)$ & 3.00 & 2.50 & 2.50 \\
Nutrient composition & & & \\
Crude protein (g/kg) & 230 & 195 & 170 \\
Metabolisable energy (MJ/kg) & 12.13 & 12.34 & 12.55 \\
Lysine (g/kg) & 14.5 & 12.5 & 10.5 \\
Methionine + cysteine (g/kg) & 9.5 & 8.5 & 7.5 \\
Tryptophan (g/kg) & 2.5 & 2.1 & 1.8 \\
Threonine (g/kg) & 9.2 & 7.9 & 6.7 \\
Calcium (g/kg) & 12.0 & 11.5 & 11.0 \\
Phosphorus (g/kg) & 6.5 & 5.5 & 5.0 \\
Sodium (g/kg) & 1.5 & 1.5 & 1.5
\end{tabular}

\footnotetext{
${ }^{1}$ Cytromix Plus: citric acid, fumaric acid, phosphoric acid (62\%).

${ }^{2}$ Farmix: Mineral and vitamin premix (per kg diet): 3000000 IU vitamin A; 900000 IU vitamin $\mathrm{D}_{3} ; 10000 \mathrm{mg}$ vitamin $\mathrm{E} ; 500 \mathrm{mg}$ vitamin $\mathrm{K}_{3} ; 700 \mathrm{mg}$ vitamin $\mathrm{B}_{1} ; 2000 \mathrm{mg}$ riboflavin; $1200 \mathrm{mg}$ vitamin $\mathrm{B}_{6} ; 6 \mathrm{mg}$ vitamin $\mathrm{B}_{12} ; 400 \mathrm{mg}$ folic acid; $72 \mathrm{mg}$ biotin; $15000 \mathrm{mg}$ niacin; $120000 \mathrm{mg}$ choline; $4200 \mathrm{mg}$ calcium pantothenicum; $30000 \mathrm{mg} \mathrm{Mn;} 18000 \mathrm{mg}$ Zn; $12000 \mathrm{mg}$ Fe; $3000 \mathrm{mg}$ $\mathrm{Cu} ; 200$ mg I; 60 mg Se; 40 mg Co; 15 g Ca.
} 
of vitamin C was determined calorimetrically in a reaction with 2,6-dichlorophenolindophenol following the method of Omaye et al. (1979). During the study, the following production indices were analysed: Body weight (at the start of experiment and at the 6th, 9th, 15th and 16th weeks of life), feed intake and feed conversion ratio. Based on the production results, the index of rearing effectiveness (WEO) was calculated (Faruga \& Pudyszak, 1999):

$$
\mathrm{WEO}=\frac{\text { mean body weight after rearing }(\mathrm{kg}) \times \text { liveability }(\%) \times 100}{\text { day of rearing } \mathrm{x} \text { feed conversion ratio }(\mathrm{kg} / \mathrm{kg})}
$$

The results obtained were analysed statistically (standard error of means (SEM), standard deviation (SD)) by analysis of variance (ANOVA), using Statistica 6.0 software (StatSoft, 1995). The $P$ values $\leq 0.01$ and $\leq 0.05$ were considered significant.

\section{Results}

The growth performance of the turkey hens is presented in Table 2. The hens receiving the additive, Bio-Mos, in their feed throughout the experimental period were heavier than those in the control, which was also reflected in weekly weigh gains. As the experiment progressed, feed intake decreased by $2.61 \%$, calculated per $1 \mathrm{~kg}$ of body mass, which was recorded also in the Bio-Mos group. The data obtained are expressed according to the European Index of Rearing Effectiveness (WEO). The value of this index was 39.7 points higher $(P \leq 0.05)$ in the Bio-Mos group (481.6 points) compared with the control group (441.9 points). The survival rate of the hens was $100 \%$.

Table 2 Growth performance of turkeys on a diet supplemented with

\begin{tabular}{|c|c|c|c|c|}
\hline \multirow{2}{*}{ Item } & & \multicolumn{2}{|c|}{ Experimental group } & \multirow{2}{*}{ SEM } \\
\hline & & Control & Bio-Mos & \\
\hline \multirow[t]{4}{*}{ Body weight (kg) } & 6 weeks & $1.79 \pm 0.06$ & $1.77 \pm 0.05$ & 0.015 \\
\hline & 9 weeks & $3.10 \pm 0.25$ & $3.69 \pm 0.2$ & 0.27 \\
\hline & 15 weeks & $8.62 \pm 0.17$ & $8.98 \pm 0.24$ & 0.31 \\
\hline & 16 weeks & $9.12^{\mathrm{b}} \pm 0.46$ & $9.68^{\mathrm{a}} \pm 0.55$ & 0.26 \\
\hline \multirow{2}{*}{\multicolumn{2}{|c|}{$\begin{array}{l}\text { Gain }(\mathrm{kg}) \\
(6-16 \text { weeks of life) } \\
\text { Feed conversion ratio }(\mathrm{kg} / \mathrm{kg}) \\
(6-16 \text { weeks of life })\end{array}$}} & 7.33 & 7.91 & 0.04 \\
\hline & & 2.68 & 2.61 & 0.02 \\
\hline \multicolumn{2}{|c|}{ WEO points } & $441.9^{\mathrm{b}}$ & $481.6^{\mathrm{a}}$ & 3.24 \\
\hline
\end{tabular}
mannanoligosaccharides (Bio-Mos)

$\overline{\mathrm{a}, \mathrm{b}}$ Means within the same row with different superscripts differ significantly $(P \leq 0.05)$. SEM: standard error of the mean.

WEO: index of rearing effectiveness.

A significant factor in assessing the effectiveness of feed additives in animal nutrition is the course of metabolic processes that is reflected, among others, in changing biochemical parameters of the blood (Ganong, 2005). The results of the analyses referring to the selected biochemical parameters of turkey hens' blood plasma are presented in Table 3. During the whole fattening period the hens receiving the additive, mannanoligosaccharides (Bio-Mos) in their feed, showed lower plasma concentrations of the non-enzymatic antioxidants, uric acid, urea and creatinine, than in the control group. During the whole experimental period the concentration of uric acid was on average 20.4\% lower than in the control. Only in the first period of administering Bio-Mos (the 9th week of life) the concentration of urea was lower $(P \leq 0.05)$ in comparison with the control group. However, during the whole fattening period the mean concentration of urea in the 
plasma declined by 21.3\%. Only at the end of the experiment (16th week of life) the creatinine concentration in the Bio-Mos group was $26.3 \%$ lower $(P \leq 0.05)$ than that in the control group. Another non-enzymatic antioxidant determined in the analyses, was bilirubin. During the first nine weeks of observation the bilirubin concentration in the plasma of the hens was similar in both treatment groups . At the end of the experiment (week 16) a drop of $20 \%$ in bilirubin concentration was recorded in the birds fed mannanoligosaccharides compared with the control group. At the 9th week, albumin concentration in plasma was similar in the two treatments, though a declining tendency of $12.5 \%$ was noted in the plasma of the turkey hens receiving BioMos. The main products of lipid oxidation are hydrogen superoxide and malone dialdehyde. An increased concentration of lipid peroxidation products proves the predominance of oxidation processes in the organism.

Table 3 Level of biochemical indices in blood plasma of turkey hens on a diet supplemented with mannanoligosaccharides (Bio-Mos)

\begin{tabular}{|c|c|c|c|c|c|c|c|}
\hline \multirow{4}{*}{$\begin{array}{l}\text { Item } \\
\begin{array}{l}\text { Uric acid } \\
(\mu \mathrm{mol} / \mathrm{L})\end{array}\end{array}$} & \multirow{4}{*}{$\begin{array}{c}\begin{array}{c}\text { Week of } \\
\text { life }\end{array} \\
9 \\
16\end{array}$} & \multicolumn{5}{|c|}{ Experimental group } & \multirow{3}{*}{$\begin{array}{l}\text { SEM } \\
0.239\end{array}$} \\
\hline & & \multicolumn{2}{|c|}{ Control } & \multicolumn{3}{|c|}{ Bio-Mos } & \\
\hline & & $280.4^{\mathrm{a}}$ & \pm 63.1 & $231.0^{\mathrm{ab}}$ & \pm & 45.1 & \\
\hline & & $266.5^{\mathrm{a}}$ & \pm 52.6 & $204.2^{\mathrm{b}}$ & \pm & 63.7 & 0.218 \\
\hline \multirow{4}{*}{$\begin{array}{l}\text { Urea } \\
(\mathrm{Mmol} / \mathrm{L})\end{array}$} & $\overline{\mathbf{x}}$ & $273.4^{\mathrm{a}}$ & $\pm \quad 57.85$ & $217.6^{\mathrm{b}}$ & \pm & 54.4 & 0.210 \\
\hline & 9 & $0.77^{\mathrm{a}}$ & \pm 0.11 & $0.52^{\mathrm{b}}$ & \pm & 0.05 & 0.010 \\
\hline & 16 & 0.68 & \pm 0.13 & 0.62 & \pm & 0.16 & 0.012 \\
\hline & $\overline{\mathbf{x}}$ & $0.72^{\mathrm{a}}$ & \pm 0.12 & $0.57^{\mathrm{b}}$ & \pm & 0.105 & 0.010 \\
\hline \multirow{3}{*}{$\begin{array}{l}\text { Creatinine } \\
(\mu \mathrm{mol} / \mathrm{L})\end{array}$} & 9 & 16.08 & \pm 3.51 & 16.79 & \pm & 3.35 & 0.139 \\
\hline & 16 & $37.19^{\mathrm{a}}$ & \pm 9.65 & $27.40^{\mathrm{b}}$ & \pm & 7.64 & 0.142 \\
\hline & $\overline{\mathbf{x}}$ & $26.63^{\mathrm{a}}$ & $\pm \quad 6.58$ & $22.09^{b}$ & \pm & 5.49 & 0.140 \\
\hline \multirow{3}{*}{$\begin{array}{l}\text { Bilirubin } \\
(\mu \mathrm{mol} / \mathrm{L})\end{array}$} & 9 & 3.85 & \pm 0.77 & 3.73 & \pm & 0.35 & 0.093 \\
\hline & 16 & $4.63^{\mathrm{a}}$ & \pm 0.49 & $3.70^{\mathrm{b}}$ & \pm & 0.24 & 0.082 \\
\hline & $\overline{\mathbf{x}}$ & $4.24^{\mathrm{a}}$ & \pm 0.63 & $3.71^{\mathrm{b}}$ & \pm & 0.29 & 0.076 \\
\hline \multirow{3}{*}{$\begin{array}{l}\text { Albumin } \\
(\mathrm{g} / \mathrm{L})\end{array}$} & 9 & 13.52 & \pm 1.40 & 13.52 & \pm & 1.48 & 0.143 \\
\hline & 16 & $15.64^{\mathrm{a}}$ & $\pm \quad 2.27$ & $13.67^{\mathrm{b}}$ & \pm & 0.97 & 0.112 \\
\hline & $\overline{\mathbf{x}}$ & 14.58 & \pm 1.83 & 13.59 & \pm & 1.22 & 0.101 \\
\hline
\end{tabular}

$\overline{\mathrm{a}, \mathrm{b}}$ Means in the same row with different superscripts differ significantly $(P \leq 0.05)$.

SEM: standard error of the mean.

Data referring to the formation of pro-oxidation-antioxidation potential in the blood plasma of the turkey hens fed Bio-Mos are presented in Table 4. At the 9th week of rearing the addition of Bio-Mos led to a reduction of $29.8 \%(P \leq 0.05)$ in the concentration of hydrogen superoxide in plasma compared with the control. However, no significant effect of administering Bio-Mos was observed on the concentration of plasma malone dialdehyde in the hens. Recorded values did not reveal any noticeable changes in the activity of superoxide dismutase in the plasma of hens receiving Bio-Mos. The additive reduced $(P \leq 0.05)$ catalase activity by $44.3 \%$ and total antioxidation potential in plasma by $24.9 \%$ compared to the control. However, this effect was observed only at the beginning of the experiment. The concentration of vitamin $\mathrm{C}$ was $126.3 \%$ higher $(P \leq 0.05)$ in the group fed Bio-Mos compared with the control group, particularly during the first period of rearing.

The concentration of mineral elements in blood plasma of the turkey hens is presented in Table 5. In the first period of administration the addition of Bio-Mos resulted in an increase $(P \leq 0.05)$ of $12.6 \%$ in the concentration of iron in blood plasma, compared with the control group, and at the 16th week an increase $(P$ $\leq 0.05$ ) of $27 \%$ in iron concentration was recorded. Throughout the rearing period the mean concentration of 
iron in blood plasma was higher than in the control group. At the 9th week of rearing zinc concentration in the plasma of the birds receiving Bio-Mos was $53 \%$ higher $(P \leq 0.05)$ than in the control group. Neither at the 9 th nor at the 16th week any noticeable changes was observed in copper concentration in the plasma of the hens.

Table 4 Level of pro-oxidants and antioxidants indices in blood plasma of turkey hens on a diet supplemented with mannanoligosaccharides (Bio-Mos)

\begin{tabular}{|c|c|c|c|c|c|c|}
\hline \multirow{2}{*}{ Item } & \multirow{2}{*}{$\begin{array}{c}\text { Week of } \\
\text { life }\end{array}$} & \multicolumn{4}{|c|}{ Experimental group } & \multirow{2}{*}{ SEM } \\
\hline & & & ontrol & $\mathrm{Bio}$ & -Mos & \\
\hline \multirow{3}{*}{$\begin{array}{l}\mathrm{H}_{2} \mathrm{O}_{2} \\
\mu \mathrm{mol} / \mathrm{L}\end{array}$} & 9 & $4.39^{\mathrm{a}}$ & \pm 1.65 & $3.08^{\mathrm{b}}$ & \pm 1.56 & 0.032 \\
\hline & 16 & 4.01 & \pm 1.36 & 5.77 & \pm 1.71 & 0.038 \\
\hline & $\overline{\mathbf{x}}$ & 4.2 & \pm 1.50 & 4.42 & \pm 1.63 & 0.034 \\
\hline \multirow{3}{*}{$\begin{array}{l}\text { MDA } \\
\mu \mathrm{mol} / \mathrm{L}\end{array}$} & 9 & 0.22 & $\pm \quad 0.08$ & 0.28 & $\pm \quad 0.08$ & 0.012 \\
\hline & 16 & 0.40 & $\pm \quad 0.11$ & 0.44 & \pm 0.13 & 0.018 \\
\hline & $\overline{\mathbf{x}}$ & 0.31 & $\pm \quad 0.09$ & 0.36 & \pm 0.10 & 0.016 \\
\hline \multirow{3}{*}{$\begin{array}{l}\text { Superoxide } \\
\text { dismutase } \\
\mathrm{U} / \mathrm{mL}\end{array}$} & 9 & 23.9 & $\pm \quad 2.02$ & 23.2 & \pm 1.60 & 0.053 \\
\hline & 16 & 15.85 & \pm 1.65 & 14.67 & $\pm \quad 2.79$ & 0.058 \\
\hline & $\overline{\mathbf{x}}$ & 19.8 & \pm 1.83 & 18.9 & $\pm \quad 2.19$ & 0.051 \\
\hline \multirow{3}{*}{$\begin{array}{l}\text { Catalase } \\
\mathrm{U} / \mathrm{mL}\end{array}$} & 9 & $7.1^{\mathrm{a}}$ & \pm 1.16 & $3.95^{\mathrm{b}}$ & \pm 1.37 & 0.023 \\
\hline & 16 & 6.81 & $\pm \quad 6.35$ & 6.85 & $\pm \quad 2.47$ & 0.031 \\
\hline & $\overline{\mathbf{x}}$ & $6.95^{\mathrm{a}}$ & $\pm \quad 3.75$ & $5.40^{\mathrm{b}}$ & $\pm \quad 1.92$ & 0.030 \\
\hline \multirow{3}{*}{$\begin{array}{l}\text { FRAP } \\
\mu \mathrm{mol} / \mathrm{L}\end{array}$} & 9 & $64.48^{\mathrm{a}}$ & \pm 4.4 & $48.40^{\mathrm{b}}$ & \pm 8.3 & 0.045 \\
\hline & 16 & 78.42 & \pm 7.4 & 79.29 & \pm 7.0 & 0.018 \\
\hline & $\overline{\mathbf{x}}$ & $71.4^{\mathrm{a}}$ & $\pm \quad 6.10$ & $63.8^{\mathrm{b}}$ & $\pm \quad 7.65$ & 0.031 \\
\hline \multirow{3}{*}{$\begin{array}{l}\text { Vitamin C } \\
\mathrm{mg} / \mathrm{L}\end{array}$} & 9 & $0.056^{\mathrm{b}}$ & \pm 0.01 & $0.17^{\mathrm{a}}$ & \pm 0.02 & 0.008 \\
\hline & 16 & $0.058^{\mathrm{b}}$ & \pm 0.01 & $0.087^{\mathrm{ab}}$ & \pm 0.04 & 0.010 \\
\hline & $\overline{\mathbf{x}}$ & $0.057^{\mathrm{b}}$ & $\begin{array}{ll} \pm & 0.01\end{array}$ & $0.129^{\mathrm{a}}$ & $\begin{array}{l} \pm \\
\pm\end{array}$ & 0.009 \\
\hline
\end{tabular}

$\overline{\mathrm{a}, \mathrm{b}}$ means in the same row with different superscripts differ significantly $(P \leq 0.05)$

SEM: standard error of the mean.

$\mathrm{H}_{2} \mathrm{O}_{2}$ : peroxides;

FRAP: total antioxidant potential of plasma;

SOD: superoxide dismutase;

MDA: malondialdehyde.

\section{Discussion}

In the present study the final body mass of the hens receiving Bio-Mos was significantly higher than that in the control. Improved performance in turkeys and chickens fed a feed supplemented with mannanoligosaccharides and $\beta$-glucan was also observed by Zduńczyk et al. (2005) and Mikulski et al. (2008). In broilers fed a diet containing mannanoligosaccharides, a significant drop in the number of pathogenic strains of Salmonella and Escherichia coli was observed, as well as an increase in the desirable intestinal bacteria of Lactobacillus spp. and Bifidobacterium types, which produce short-chain fatty acids and reduce the $\mathrm{pH}$ of the intestinal contents and thus create an unfavourable environment for pathogens (Baurhoo et al., 2007). Hence, improved rearing effects are related to the beneficial influence of the components of the cellular wall of Saccharomyces cerevisiae yeast on the development, morphology and metabolism indices in turkeys and chickens (Zaghini et al., 2005). Changes in the morphology of intestines and metabolic indices resulted in better digestion, better absorption of nutrients in the small intestine, improved specific immunity and increased weight gains (Lecewicz et al., 2008). 
Table 5 Concentration of microelements in blood plasma of turkey hens on a diet supplemented with mannanoligosaccharides (Bio-Mos)

\begin{tabular}{|c|c|c|c|c|c|c|c|}
\hline \multirow{2}{*}{ Item } & \multirow{2}{*}{ Week of life } & \multicolumn{5}{|c|}{ Experimental group } & \multirow{2}{*}{ SEM } \\
\hline & & & ntrol & & Bio- & Mos & \\
\hline \multirow{3}{*}{$\begin{array}{l}\text { Iron } \\
\mu \mathrm{mol} / \mathrm{L}\end{array}$} & 9 & $57.73^{\mathrm{b}}$ & \pm 6.1 & $65.02^{\mathrm{a}}$ & \pm & 6.2 & 0.047 \\
\hline & 16 & $27.30^{\mathrm{b}}$ & \pm 4.3 & $34.68^{\mathrm{a}}$ & \pm & 3.7 & 0.083 \\
\hline & $\overline{\mathbf{x}}$ & 42.5 & \pm 5.2 & 49.8 & \pm & 4.95 & 0.054 \\
\hline \multirow{3}{*}{$\begin{array}{l}\text { Zinc } \\
\mu \mathrm{mol} / \mathrm{L}\end{array}$} & 9 & $18.5^{\mathrm{b}}$ & \pm 1.02 & $28.29^{\mathrm{a}}$ & \pm & 2.5 & 0.042 \\
\hline & 16 & 31.8 & \pm 1.2 & 32.3 & \pm & 2.4 & 0.031 \\
\hline & $\overline{\mathbf{x}}$ & $25.1^{\mathrm{b}}$ & \pm 1.11 & $30.3^{\mathrm{a}}$ & \pm & 2.45 & 0.033 \\
\hline \multirow{3}{*}{$\begin{array}{l}\text { Copper } \\
\mu \mathrm{mol} / \mathrm{L}\end{array}$} & 9 & 3.24 & \pm 1.09 & 2.77 & \pm & 0.89 & 0.038 \\
\hline & 16 & 4.98 & \pm 0.38 & 5.52 & \pm & 0.59 & 0.035 \\
\hline & $\overline{\mathbf{x}}$ & 4.11 & \pm 0.735 & 4.14 & \pm & 0.74 & 0.031 \\
\hline
\end{tabular}

a,b - means in the same row with different superscripts differ significantly $(P \leq 0.05)$.

SEM: standard error of the mean.

The supplementation of Bio-Mos resulted in a significant decrease the concentration of uric acid in the plasma. A similar result was observed in sheep fed Bio-Mos during lactation (Czech et al., 2006). On the other hand, Truchliński et al. (2005), who administered $\beta$-glucan, an additive with properties similar to that of mannanoligosaccharides, to turkey hens, did not observe a significant change in the concentration of uric acid in plasma. Urea is the final product of protein-nitrogen metabolism in the organism. An increase in urea concentration, similar to uric acid, in blood plasma may indicate oxidation stress and may result from an organism's adaptation at the initial stage of increased generation of oxygen's reactive forms (Landmesser \& Drexler, 2002). This is confirmed by results of research performed on rats with acute pancreatitis (free radical reactions and oxidation stress play a significant role in the pathogenesis of this disease) (Barham et al., 2006). The lower levels of uric acid and urea in the blood of turkey hens fed mannanoligosaccharides, which was observed in the present study, may suggest that Bio-Mos have the ability to adsorb pathogenic microorganisms on its surface and facilitate their destruction through specialized cells of the immune system (Mikulski et al., 2008), thus eliminating potential inflammatory conditions and the oxidation stress that accompanies them. The results obtained in the present study revealed a significant reduction in the level of urea after three weeks of administering Bio-Mos. A significant decrease in the concentration of urea was also recorded by Czech et al. (2006) in the study on sheep fed manganese oligosaccharides, by Dobicki et al. (2007) using cows, and by Czech \& Grela (2006) studying mares fed a mixture supplemented with mannanoligosaccharides.

The results of the analyses suggest a significant lowering of the concentrations of bilirubin, albumin and creatinine. A drop in the concentration of bilirubin in the plasma of turkey hens given a mixture of synthetic antioxidants was observed by Czech \& Ognik (2006). Bilirubin results from disintegration of haeme that has been released from haemoglobin in the bone marrow, spleen and liver during the catabolism of erythrocytes. Bilirubin is one of low-molecule antioxidants acting in the aqueous stage, which interrupts free-radical processes by reacting with reactive forms of oxygen, and neutralizing them (Arivazhagan et al., 2000). Albumin constitutes $60 \%$ of total protein in plasma. Various substances are transported in the blood in combination with albumins. These proteins bind the ions of transitory metals and reduce the intensity of freeradical reactions (Dobicki et al., 2007). Albumins are regarded as preventive antioxidants because they prevent the formation of reactive oxygen forms, particularly the creation of hydroxyl radical (PawłowskaGóral et al., 2003). Dobicki et al. (2007) did not observe any significant differences in the level of albumins in the plasma of cows receiving dried brewer's yeast, yet they noted a declining tendency of this index. Creatinine is the main metabolite of skeletal muscles, resulting from metabolic changes that occur in muscle (Pawłowska-Góral et al., 2003). Increased creatinine production is caused by physical effort, which is related 
to a higher demand by cells for oxygen and a higher number of reactive oxygen forms generated in the organism (Moffarts et al., 2005). Hydrogen superoxide is created as a result of two electrons joining with an oxygen molecule, with the participation of metal-flavin enzymes (e.g. xanthine oxidase, which oxidizes xanthine to uric acid) or as a consequence of an electron joining with a superoxide anion-radical in a reaction of dismutation catalyzed by superoxide dismutase. It is a particularly powerful inhibitor of enzymatic systems (Escobar et al., 1996). A lower level of hydrogen superoxide in the blood of the hens fed the BioMoss, as observed in the current study, may suggest that mannanoligosaccharides increase the efficiency of the antioxidation barrier through their immunostimulating activity and eradicating effectively pathogenic agents, and thus reducing the generation of free radicals (Mikulski et al., 2008). A decrease in the concentration of hydrogen superoxide in the plasma of the turkey hens fed an addition of Bio-Mos was correlated with a significant reduction in the activity of catalase in the birds almost for the duration of the experiment. The studies by Czech \& Ognik (2010) showed that an addition of a mixture of synthetic antioxidants does not change the content of malone dialdehyde significantly, i.e. the final product of lipid oxidation in hens' blood, either. On the other hand, a reduction in the concentration of this particular parameter in the tissues of pigs fed an antioxidation additive (selenomethionine) is suggested by the results of Zhan et al. (2007). In the case of using mannanoligosaccharides in animal nutrition, the majority of studies focused on assessing the effect of their activity on biochemical, haematological or immunological indices. However, the available literature lacks any data referring to the effect of Bio-Mos additive on the antioxidation system, especially that of poultry.

Antioxidant enzymes are most effective when acting synergistically with one another or with other components of the antioxidant barrier of the organism when their activity remains balanced. Among the enzymes with antioxidant activity, the indices most frequently used to assess the organism's antioxidant condition are superoxide dismutase and catalase (Lutnicki et al., 2006). In the present study no effect of BioMOS on the superoxide dismutase activity was observed in the plasma of the turkey hens. This might suggest that this resulted from a pro-oxidation-antioxidation balance in the organism. The administration of mannanoligosaccharides in different diseases and during pregnancy contributes to the stimulation of the antioxidant potential in the organism of animals exposed to stressful situations. This is confirmed by the studies performed by Czech \& Grela (2006), who observed a higher activity of superoxide dismutase in the plasma of pregnant mares receiving an addition of mannanoligosaccharides. A similar effect provoked by using this preparation in sheep during the period of their pregnancy and lactation is indicated by the research of Czech et al. (2006). An increase in catalase activity at the beginning of the experiment caused by using mannanoligosaccharides may be because Bio-Mos limits the intensity of pathological conditions owing to the elimination of pathogenic agents and the fighting of intestinal infections, and thus reducing the stimulation of antioxidation processes. Similar results were noted by Czech et al. (2006) in sheep fed mannanoligosaccharides during lactation. Catalase is an enzyme responsible for reducing hydrogen superoxide to water and oxygen. Numerous scholars (Gutowicz et al., 2008; Lecewicz et al., 2008) stated that an increase in the activity of catalase in the blood is caused by environmental burdens to which birds are exposed during their growth. Ogryczak et al. (2001) observed that reduced catalase activity typically occurs at the beginning of a pathological condition, while it increases after recovery or during chronic conditions. Generally, stressful situations and diseases are accompanied by a higher activity of catalase, which disintegrates the accumulated hydrogen superoxide. An increase in catalase during pregnancy of sheep fed a feed mixture enriched with mannanoligosaccharides was recorded by Czech et al. (2006). An increase in catalase activity in the blood of turkeys was also observed when feeding them additives (particularly herbs) with biostimulating properties (Ilavarasan et al., 2003; Konyalioglu \& Karamenderes, 2005; Gutowicz et al., 2008). The total antioxidation potential of the blood plasma, FRAP (ferric reducing ability of plasma), consisted of uric acid (60\%), ascorbic acid (15\%), glutathione (10\%) and tocopherols (5\%) concentrations. Reducing the value of the total antioxidation potential in the blood plasma of the birds fed Bio-Mos in the first period of introducing this additive, may result from a statistically relevant drop in the level of uric acid, the major component of FRAP. Increasing the value of FRAP is usually a desirable phenomenon because it guarantees better protection for cells and tissues against the toxic activity of reactive forms of oxygen. A higher total antioxidation potential in the blood plasma of the control birds, however, may be a reflection of the birds' adaptation to oxidative stress (Moffarts et al., 2005). The majority of health problems, frequently resulting from stressful rearing conditions, occurs in turkeys at the initial stage of breeding in particular. An increase in the total antioxidation potential was observed (Truchliński et al., 2005) in the blood of sheep that 
were fed mannanoligosaccharides during pregnancy and lactation. Increased FRAP was also noted in birds and people administered immunostimulating additives (Carini et al., 2001; Csuka et al., 2005; Duthie et al., 2006; Ognik \& Sembratowicz, 2007).

The cellular system of neutralizing harmful activities of free radicals and lipid superoxides includes antioxidant vitamins, for example vitamin C. Vitamin C plays the role of an effective tissue antioxidant (Choi et al., 2004). Turkeys have the ability to synthesize ascorbic acid, yet during intensive rearing their own synthesis is often insufficient to satisfy their metabolic needs. Mannanoligosaccharides, which reduce the intensity of pathologic conditions through stimulating natural defence mechanisms, partly release the birds' organism from stress and the resulting vitamin C insufficiency, and thus improve the birds' immunity to unfavourable environmental conditions (Świątkiewicz \& Koreleski, 2007).

Among the numerous mineral elements that may participate in antioxidation reactions, special attention should be paid to the ions of transitory metals, copper, zinc and iron, as they constitute the catalytic centres of enzymes. Their optimal concentration in blood plasma guarantees the proper functioning of antioxidant enzymatic centres (Kleczkowski et al., 2004). A decrease in the concentration of these components may suggest their utilization in the body for the sake of antioxidation protection, whereas a rise in their levels may mean that the organism is free from stress or the effect of such stress is not too oppressive. An increase in the concentration of iron correlated with a lower activity of catalase, which was observed during the initial rearing period, is difficult to interpret since iron is a co-factor of this enzyme and equips it with antioxidant properties. A higher iron level in turkey hens of the Bio-Mos group may be a consequence of a substantial increase in vitamin $\mathrm{C}$ content in the blood plasma of the birds receiving BioMos, because the presence of vitamin C favours the assimilability of iron by up to $50 \%$ (Ognik \& Sembratowicz, 2007). A rise in the iron level in sheep fed an addition of mannanoligosaccharides during lactation was noted by Czech et al. (2006). On the other hand, Czech \& Grela (2006), who administered BioMos to pregnant mares, observed a lower level of iron correlated with an increased catalase activity. Czech \& Grela (2006) recorded an increased concentration of zinc in the plasma of mares supplemented with a mixture of mannanoligosaccharides. Zinc reveals antioxidant properties only in a situation when it occurs in concentrations higher than normal in body fluids or tissues. The antioxidant mechanism of zinc consists of inhibiting the production of reactive oxygen forms and protecting thiol groups against oxidation. It also participates in creating the activity of superoxide dismutase and glutathione peroxidase. On the other hand, copper functions as an antioxidant only in a situation when it becomes a component of superoxide dismutase or caeruloplasmin. Besides zinc, manganese and iron, copper ions are superoxide dismutase activators (Kleczkowski et al., 2004).

To sum up, it should be emphasized that the Bio-Mos preparation isolated from yeast walls contributed to improved performance of the turkey hens. The administration of the natural Bio-Mos preparation did not induce the number of lipid peroxidation products $\left(\mathrm{H}_{2} \mathrm{O}_{2}\right.$ and MDA). However, it resulted in stimulating the antioxidation system, which was reflected in reducing the concentration of uric acid, urea, creatinine, catalase and FRAP, as well as increasing the concentration of vitamin C, iron and zinc. Hence, mannanoligosaccharides may have a practical application as a feed additive for turkeys, improving production effectiveness and stimulating antioxidant mechanisms of the animal.

\section{References}

Arivazhagan, P., Thilakavathy, T. \& Panneerselvam, Ch., 2000. Antioxidant lipoate and tissue antioxidants in aged rats. J. Nutr. Biochem. 11, 122-127.

Barham, S., Truchliński, J. \& Ognik, K., 2006. Peroxidation of lipids in rats. Organs during acute pancreatitis. Medicin Wet. 62 (4), 440-443. (in Polish).

Bartosz, G., 2004. Oxygen's second face. PWN, Warsaw. (in Polish).

Baurhoo, B., Letellier, A., Zhao, X. \& Ruiz- Feria, C.A., 2007. Cecal populations of Lactobacilli and Bifidobacteria and Escherichia coli populations after in vivo Escherichia coli challenge in birds fed diets with purified lignin or mannanooligosaccharides. Poult. Sci. 86, 2509-2515.

Benzie, I.F.F. \& Strain, J.J., 1996. The ferric reducing ability of plasma (FRAP) as a measure of antioxidant power: the FRAP assay. Anal. Biochem. 239, 70-76.

Carini, M., Aldini, G., Rossoni, G., Morazzoni, P. \& Facino, R.M., 2001. Complexation of Ginkgo biloba extract with phosphatidylcholine improves cardioprotective activity and increases the plasma antioxidant capacity in the rat. Planta Med. 67 (4), 326-330. 
Choi, S.W., Benzie, I.F. \& Collins, A.R., 2004. Vitamines C and E: acute interactive effects on biomarkers of antioxidant defence and oxidative stress. Mut. Res. 551, 109-117.

Csuka, G., Bardos, L. \& Agota, G., 2005. Effect of the dietary administration of natural antioxidants ( $\beta$ carotene, vitamin $\mathrm{E}$ and rosemary powder) for the prevention of harmful effects of oxidized lipids: model experiments on Japanese quail. Hungar Vet. J. Magyar-Allatorvosok-Lapja 127 (7), 413-421.

Czech, A. \& Grela, E.R., 2006. Influence of Bio-Mos mannan oligosaccharides in mare diets on colostrum and milk composition and blood parameters. In: Nutritional Biotechnology in the Feed and Food Industries, Proceedings of Alltech’s 22st Annual Symposium, Eds Lyons, T.P. \& Jacques, K.A. pp. 301-310.

Czech, A. \& Ognik, K., 2010. The effect of a synthetic antioxidant mixture on metabolism indices in turkey hens. Zesz. Prob. Post. Nauk Rol. 550, 45-52. (in Polish).

Czech, A., Klebaniuk, R. \& Ognik, K., 2006. Influence of mannan-oligosaccharide prebiotic (MOS) and probiotic (Microbisan) feed additives on the haematology and antioxidant parameters of ewe's blood. Pol. J. Nat. Sci. 3, 171-176. (in Polish).

Czech, A., Mokrzycka, A., Grela, E.G. \& Pejsak, A., 2009. Influence of mannanoligosacharids additive to sow diets on blood parameters of sows and their piglets. Bull. Vet. Inst. Pulawy. 53, 89-95. (in Polish).

Dobicki, A., Preś J., Zachwieja, A., Mordak, R. \& Jakus, W., 2007. The effect of yeast preparations on selected biochemical blood parameters and the composition of cow's milk. Medicin Wet. 63 (8), 955-959. (in Polish).

Duthie, S.J., Jenkinson, A.M., Crozier, A., Mullen, W., Pirie, L. \& Kyle, J., 2006. The effects of cranberry juice consumption on antioxidant status and biomarkers relating to heart disease and cancer in healthy human volunteers. Eur. J. Nutr. 45 (2), 113-122.

Escobar, J.A., Rubio, M.A. \& Lissi, E.A., 1996. SOD and catalase inactivation by singlet oxygen and peroxyl radicals. Free Rad. Biol. Med. 20 (3), 285-290.

Faruga, A. \& Jankowski, J., 1994. Turkey - breeding and using. PWRiL 1996, Warsaw. (in Polish).

Faruga, A. \& Pudyszak, K., 1999. Rearing efficiency and meat quality of slaughter turkey-hens fed with fodder supplemented with herbs. Zesz. Nauk. Prz. Hod. 45, 349-357 (in Polish).

Ganong,W., 2005. Review of Medical Physiology. 22 ${ }^{\text {nd }}$. ed., Publisher McGraw-Hill.

Gay, C. \& Gębicki, J.M., 2002. Perchloric acid enhances sensitivity and reproducibility of the ferric- xylenol orange peroxide assay. Anal. Biochem. 304, 42-46.

Greenwald, R.A., 1985. CRC Handbook of Methods for Oxygen Radical Research. CRC Press, Boca Raton.

Gutowicz, M., Chołojczyk, M., Pyrzanowska Rutowicz, M., Chołojczyk, M., Pyrzanowska, J., WidyTyszkiewicz, E. \& Barańczyk-Kuźma, A., 2008. Effect of curcumin on antioxidant and detoxification mechanisms in the livers of aging rats. Medicin Wet. 64 (7), 955-957. (in Polish).

Ilavarasan, R., Vasudevan, M., Anbazhagan, S. \& Venkataraman, S., 2003. Antioxidant activity of Thespesia populnea bark extracts against carbon tetrachloride- induced liver injury in rats. J. Ethnopharm. 87, 227-230.

Kleczkowski, M., Kluciński, W., Sikora, J. \& Kasztelan, R., 2004. The role of selected mineral elements in the oxidation processes of the organism. Medicin Wet. 60 (3), 242-244. (in Polish).

Konyalioglu, S. \& Karamenderes, C., 2005. The protective effects of Achillea L. species native in turkey against $\mathrm{H}_{2} \mathrm{O}_{2}$-induced oxidative damage in human erythrocytes and leucocytes. J. Ethnopharm. 102 (2), 221-227.

Landmesser, U. \& Drexler, H., 2002. Allopurinol and Endothelial Function in Heart Failure. A. Heart Assoc. 106, 173-175.

Lecewicz, A., Jankowski, J., Zduńczyk, Z. \& Juśkiewicz, J., 2008. Selected factors stimulating the development of some gastrointestinal parts in turkeys. Medicin Wet. 64 (10), 1184-1186. (in Polish).

Ledwożyw, A., Michalak, J., Stępień, A. \& Kędziołka, A., 1986. The relationship between plasma triglicerydes, cholesterol, total lipids and lipid peroxidation products during human atherosclerosis. Clin. Chim. Acta. 155, 275-284.

Lutnicki, K., Szpringer, E. \& Marcinak, A., 2006. Ethanol evoked oxidation-antioxidation imbalance in rats. Medicin Wet. 62 (6), 683-685. (in Polish).

Mikulski, D., Kozłowski, K., Jankowski, J., Blok, J. \& Sobolewski, Z., 2008. Efficacy of yeast extract Saccharomyces cerevisiae in turkey feeding. Medicin Wet. 64 (11), 1331-1334. (in Polish). 
Milewski, S., 2009. Effect of yeast preparations Saccharomyces cerevisiae on meat performance traits and blood hematological indices in sucking lambs. Medicin Wet. 65 (1), 51-54. (in Polish).

Milewski, S., Wójcik, R., Małaczewska, J., Trapkowska, S. \& Siwicki, A.K., 2007. Effect of b-1.3/1.6-Dglucan on meat performance and non-specific humoral defense mechanisms in lamb. Medicin Wet. 63 (3), 360-362. (in Polish).

Moffarts, B., Kirschvink, N., Art, T., Pincemail, J. \& Lekeux, P., 2005. Effect of oral antioxidant supplementation on blood antioxidant status in trained thoroughbred horses. Vet. J. 169, 65-74.

NRC, 1994. Nutrient Requirements of Poultry. Ninth Revised Edition. Washington, D.C. National Academy Press, USA.

Ognik, K. \& Sembratowicz, I., 2007. Influence of Biostymina and Bioaron C on some anti-oxidation indices of turkey hens' blood. P. J. Environ. Stud. 16 (3a), 209-212.

Ogryczak, D., Jurek, A., Kleczkowski, M., Kluciński, W., Sitarska E., Sikora J., Kasztelan, R. \& Shaktur, A., 2001. Activity of superoxide dismutase in the blood of cows at different supply of minerals. J. Elemen. 6 (4), 616-622. (in Polish).

Oguz, H. \& Parlat, S.S., 2004. Effects of dietary mannanoligosaccharide on performance of Japanese quail affected by aflatoxicosis. S. Afr. J. Anim. Sci. 34 (3), 144 -148.

Omaye, S.T., Turnbull, J.D. \& Sauberlich, H.E., 1979. Selected methods for determination of ascorbic acid in animal cells, tissues and fluids. Meth. Enzymol. 62, 3-11.

Parks, C.W., Grimes, J.L. \& Ferket, P.R., 2005. Effects of virginiamycin and a mannanoligosaccharivirginiamycin shuttle program on the growth and performance of Large White female turkeys. Poult. Sci. 84, 1814-1973.

Pawłowska-Góral, K., Kałamarz, A. \& Wardas, M., 2003. The total antioxidation potential, methods of its measurement and its clinical usefulness. Diagn. Lab. 39, 327-338. (in Polish).

Świątkiewicz, S. \& Koreleski, J., 2007. Feed additives enhancing immune responses in poultry. Medicin Wet. 63 (11), 1291-1294. (in Polish).

Truchliński, J., Smelkowska, B., Ognik, K. \& Sembratowicz, I., 2005. Influence of beta-glucan and herb of nettle on some parameters of blood of turkey hens. Annal. UMCS s EE, 23 (44), 335-341. (in Polish).

Zaghini, A., Martelli, G., Roncada, P., Simioli, M. \& Rizzi, L., 2005. Mannanooligosaccharides and aflatoxin B1 in feed for laying hens: effects on egg quality, aflatoxins B1 and M1 residues in eggs, and aflatoxin B1 levels in liver. Poult. Sci. 84, 825-830.

Zduńczyk, Z., Juskiewicz, J., Jankowski, J., Biedrzycka, E. \& Koncicki, A., 2005. Metabolic response of the gastrointestinal tract of turkeys to diets with different levels of mannan- oligosaccharide. Poult. Sci. 84, 903-909.

Zhan, X., Wang, M., Zhao, R., Li, W. \& Xu, Z., 2007. Effects of different selenium source on selenium distribution, loin quality and antioxidant status in finishing pigs. Anim. Feed Sci. Technol. 132, 202-211. 